\title{
Carbon Dioxide Emission from Soil
}

\author{
Md. Mizanur Rahman
}

Received: 7 October 2012/ Accepted: 2 April 2013/Published online: 21 April 2013

(C) NAAS (National Academy of Agricultural Sciences) 2013

\begin{abstract}
Global warming and climate change are a cause for great concern demanding intensive research on $\mathrm{CO}_{2}$ emission from soil under different management options. Therefore, a pot experiment was conducted using

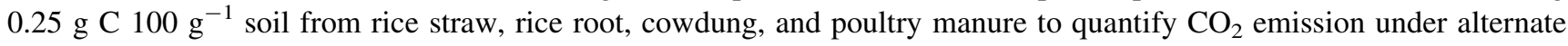
wetting and drying and continuously moist conditions. The maximum emission was recorded during the first week of incubation and after 3 weeks, it came down sharply and finally approached almost zero to $5 \mathrm{mg} \mathrm{CO} \mathrm{day}^{-1} \mathrm{~kg}^{-1}$ irrespective of organic materials and water management. Among the organic materials, cowdung released less $\mathrm{CO}_{2}$ and increased carbon content in soil. During 118 days of incubation, cumulative emissions were 158, 313, 366, 283, $576 \mathrm{mg}$ $\mathrm{CO}_{2} 100 \mathrm{~g}^{-1}$ from soil, soil plus rice straw, soil plus rice roots, soil plus cowdung, and soil plus poultry manure, respectively. Alternate wetting and drying condition released more $\mathrm{CO}_{2}$ than that under continuously moist condition. Application of cowdung in agriculture can restrict $\mathrm{CO}_{2}$ emission. From the findings it could be apprehended that before application to soil, composting of organic materials through anaerobic digestion might be the best option to reduce $\mathrm{CO}_{2}$ emission, and thus help mitigate global warming.
\end{abstract}

Keywords Carbon dioxide emission $\cdot$ Cowdung $\cdot$ Poultry manure $\cdot$ Rice straw $\cdot$ Rice roots

\section{Introduction}

Carbon dioxide $\left(\mathrm{CO}_{2}\right)$ is an important greenhouse gas accounting for $60 \%$ of the total greenhouse effect [17]. It is well known that vegetation and soils are major storage sinks of atmospheric $\mathrm{CO}_{2}$ [4]. In the last few decades, there has been an increase in the emission of naturally occurring greenhouse gases like $\mathrm{CO}_{2}$, methane $\left(\mathrm{CH}_{4}\right)$, and nitrous oxide $\left(\mathrm{N}_{2} \mathrm{O}\right)$. These gases trap outgoing infrared radiation from the earth's surface. Human health, terrestrial and aquatic ecological systems, agriculture, forestry, fisheries, and water resources are sensitive to changing climate. The concentration of $\mathrm{CO}_{2}$ in the atmosphere has increased from 280 ppmv at beginning of the industrial revolution to the

Md. M. Rahman ( $\square)$

Department of Soil Science, Bangabandhu Sheikh Mujibur Rahman Agricultural University, Gazipur 1706, Bangladesh e-mail: mizan@bsmrau.edu.bd present day value of $391 \mathrm{ppmv}$ [25]. This increase is attributed to the anthropogenic activities like agriculture and land use changes, burning of fossil fuel, deforestation, emission from automobiles, forest fires, etc. Soil organic carbon (SOC) is of paramount importance with respect to availability of plant nutrients and improvement of physical, chemical, and biological properties of soils [9]. Maintenance of SOC is essential for the sustainable agricultural production as declining soil $\mathrm{C}$ generally decreases crop productivity [11]. The SOC pool in agricultural lands is capable of enhancing agricultural sustainability and serving as a potential sink of atmospheric $\mathrm{CO}_{2}$ [5]. Carbon stocks are not only critical for the soil to perform its productivity and environmental functions but also play an important role in the global $\mathrm{C}$ cycle. Soil $\mathrm{C}$ sequestration can improve soil quality and reduce the contribution of agriculture to $\mathrm{CO}_{2}$ emissions.

Concentration of $\mathrm{CO}_{2}$ in the atmosphere has been increasing at the rate of $3.2 \times 10^{15} \mathrm{~g} \mathrm{C}_{\text {year }}{ }^{-1}$ [6], where 
the contribution of agriculture and land use change is $20 \%$ [10]. To offset climate change, the emissions of $\mathrm{CO}_{2}$ and other greenhouse gases must be reduced. The rate of soil carbon emission is strongly regulated by the amount and types of organic materials added to soil and the complex interaction among soil physical, chemical, and biological processes and environmental conditions like temperature, alternate wetting and drying, etc. [1,12]. Carbon dioxide is released from the soil through soil respiration, where soil microflora contributes $99 \%$ of the $\mathrm{CO}_{2}$ arising from decomposition of organic matter under alternate wetting and drying and flooded conditions. Soil aerobic conditions produce $\mathrm{CO}_{2}$, while anaerobic conditions produce $\mathrm{CH}_{4}$ depending on the concentration of SOC. Large quantities of organic carbon added to soils through different manures and wastes to supply plant nutrients may significantly contribute to $\mathrm{CO}_{2}$ emission. However, proper management of organic manures and wastes, conservation tillage, microaggregation, and mulching can play an important role in reducing $\mathrm{CO}_{2}$ emission, and thus increase $\mathrm{C}$ sequestration in soil [19]. The global concerns about the effect of climate change demand intensive research on carbon cycling, its transformation under different crops, soil and water management practices, and stability of carbon compounds in soils [16]. Emission of $\mathrm{CO}_{2}$ from the soil results in lessening of soil organic pool, and thus exerts effects on soil structure, soil fertility, and productivity. Therefore, reducing $\mathrm{CO}_{2}$ emission through carbon sequestration in the soil is of prime importance. Scarce information on $\mathrm{CO}_{2}$ emission from various organic residues and manures under different water management practices has forced us to carry out the research. It was hypothesized that emission of $\mathrm{CO}_{2}$ may vary with the types of organic residues added to soil and water management options. The objectives of the research were to determine the rates of $\mathrm{CO}_{2}$ emission from added organic materials in soils under alternate wetting and drying and continuously moist conditions and to identify the organic material which restricts $\mathrm{CO}_{2}$ emission in soil.

\section{Materials and Methods}

The experiment was conducted in the laboratory of Soil Science, Bangabandhu Sheikh Mujibur Rahman Agricultural University (BSMRAU), Bangladesh during MayAugust 2011.

\section{Study Soils and Organic Materials Used}

The soil used in the study was collected from the experimental farm of the BSMRAU located at $24.09^{\circ}$ north latitude and $90.26^{\circ}$ east longitude with an elevation of $8.4 \mathrm{~m}$ from the mean sea level, which is classified as shallow red brown terrace soil and inceptisols as Bangladesh and USDA classification system, respectively. The soil is under the agro-ecological zones of Madhupur Tract, which is acidic in nature having $\mathrm{pH} 6.0$ and low in organic carbon $(0.34 \%)$. After collection of soil, it was air dried and ground to a suitable label for using in the experiment. The organic materials used in the study were rice straw, rice roots, cowdung and poultry manure. Before starting the experiment, soil and above mentioned organic residues and manures were analyzed for total nitrogen and organic carbon (Table 1). Carbon contents in rice straw were the highest $(40 \%)$ followed by rice roots, poultry manure, and cowdung. Carbon contents in rice straw were almost double over that of poultry manure.

\section{Treatments and Design}

It was a two-factorial (residues $\times$ water management) experiment laid out in a randomized complete block design with two replications using rice straw, rice roots, cowdung, and poultry manure as a source of $\mathrm{C}$ at the rate of

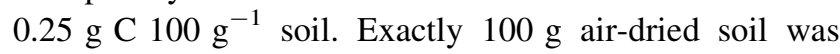
used in 1,100-ml-sized 36 airtight plastic pots. Residues were added to plastic pots as per $\mathrm{C}$ rates and mixed well with soil. The residues were control (soil); soil + rice straw; soil + rice root; soil + cowdung; soil + poultry manure; rice straw; rice root; cowdung; and poultry manure, while water management options were alternate wetting and drying and continuously moist conditions. The plastic pots along with residues and soil were incubated at a temperature of $24{ }^{\circ} \mathrm{C}$, which was maintained from 8 a.m. to 12 p.m. throughout the experimental period through an air condition.

\section{Carbon Dioxide Emission Measurement}

Carbon dioxide emission was measured by a standard method [7]. The study was conducted for 120 days (4 months). During the first 2 months, carbon dioxide emission was measured twice a week and the next 2 months once a week. $\mathrm{A} \mathrm{CO}_{2}$ trap was prepared using

Table 1 Moisture, total nitrogen, carbon contents, and C:N ratio of residues and manure used in the experiment (mean $\pm \mathrm{SD}$ )

\begin{tabular}{llllr}
\hline Residues & $\begin{array}{l}\text { Moisture } \\
\text { content }(\%)\end{array}$ & $\begin{array}{l}\text { Total nitrogen } \\
(\%)\end{array}$ & OC (\%) & $\begin{array}{l}\text { C:N } \\
\text { ratio }\end{array}$ \\
\hline $\begin{array}{l}\text { Cowdung } \\
\text { Poultry } \\
\text { manure }\end{array}$ & $21.16 \pm 3.14 \pm 2.18$ & $1.22 \pm 0.10$ & $18.50 \pm 0.21$ & 15.16 \\
Rice straw & $15.34 \pm 1.76$ & $0.44 \pm 0.08$ & $40.17 \pm 0.15$ & 91.30 \\
Rice root & $15.21 \pm 1.33$ & $0.38 \pm 0.10$ & $32.37 \pm 0.20$ & 85.18 \\
\hline
\end{tabular}


Fig. 1 Carbon dioxide emission from organic residues under alternate wetting and drying and moist conditions, a soil, soil plus rice straw, and soil plus rice roots, b soil plus cowdung and soil plus poultry manure, $\mathbf{c}$ rice straw, rice roots, cowdung, and poultry manure $A W D$ alternate wetting and drying, $C M$ continuously moist, $C D$ cowdung, $P M$ poultry manure, $R S$ rice straw, $R R$ rice root
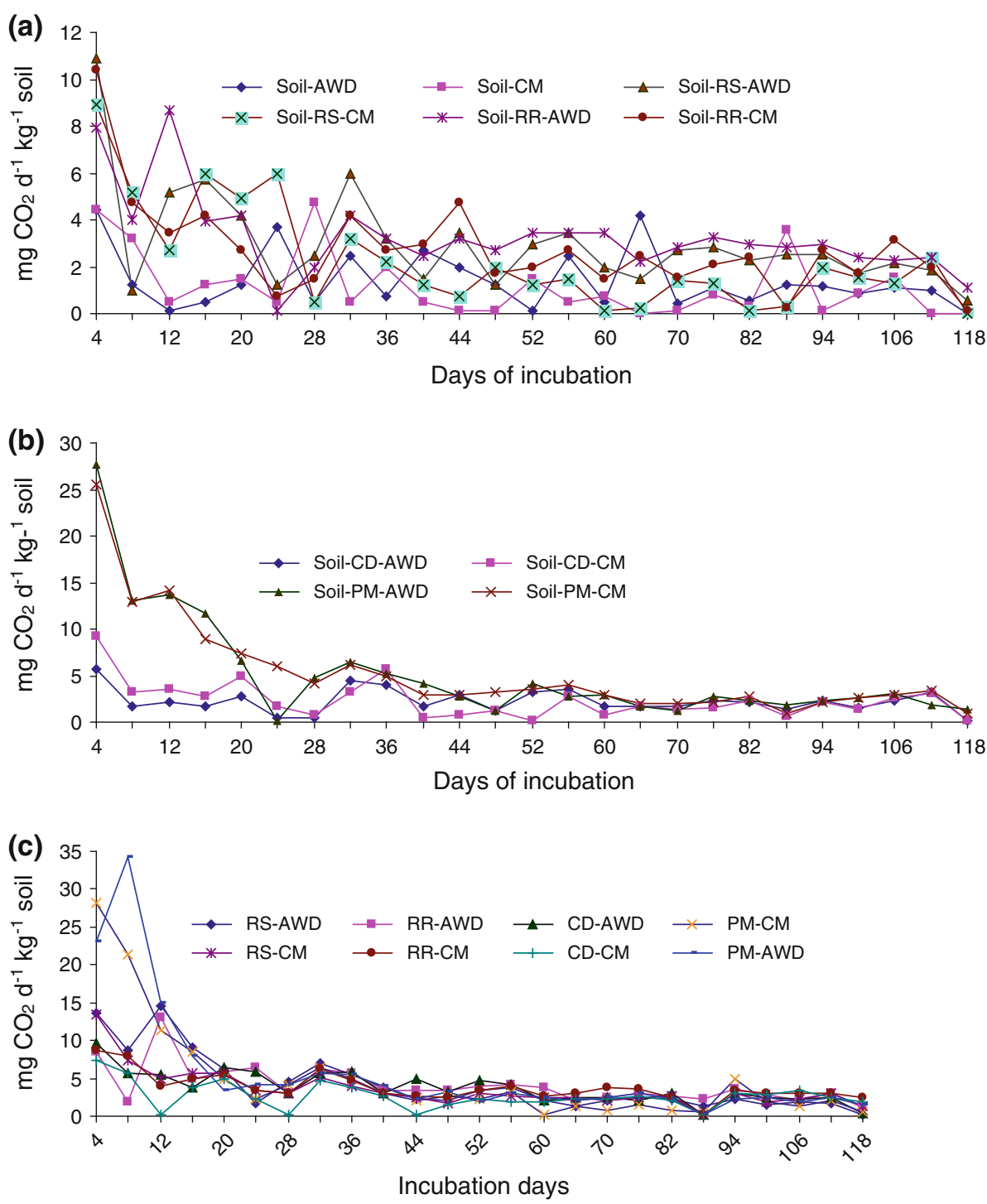

$\mathrm{NaOH}$ solution $(20 \mathrm{ml} 1.0 \mathrm{~N} \mathrm{NaOH}+25 \mathrm{ml}$ distilled water) in vial for trapping $\mathrm{CO}_{2}$. The trap solution in a beaker was placed in the air-tight plastic pots of the experiment. For first 2 months after 4 days of exposure and the next 2 months after 7 days of exposure, the alkali beakers were removed and titrated with $0.1 \mathrm{~N} \mathrm{HCl}$ solution using phenolphthalein indicator and $\mathrm{BaCl}_{2}$ solutions. Controls for this experiment consist of plastic pot without soil and residues but with the alkali of same strength was used. The alkali solutions from the control and those exposed to soil air were titrated to determine the quantity of alkali that has not reacted with $\mathrm{CO}_{2}$. For this purpose, excess $\mathrm{BaCl}_{2}$ was added to the $\mathrm{NaOH}$ solution to precipitate the carbonate as insoluble $\mathrm{BaCO}_{3}$. A few drops of phenolphthalein were added as indicator, and titrated with $0.1 \mathrm{~N} \mathrm{HCl}$ directly in the beaker. The acid was added slowly to avoid contact with possible dissolution of the precipitated $\mathrm{BaCO}_{3}$. The volume of acid needed to titrate the alkali was noted. The amount of $\mathrm{CO}_{2}$ evolved from the soil during exposure to alkali was calculated using the formula:

Milligrams of $\mathrm{C}$ or $\mathrm{CO}_{2}=(B-V) N E$

where $B$ is the volume $(\mathrm{ml})$ of acid needed to titrate $\mathrm{NaOH}$ in the jars from the control cylinders, $V$ is the volume $(\mathrm{ml})$ of acid needed to titrate the $\mathrm{NaOH}$ in the beakers exposed to the soil atmosphere, $N$ is the normality of the acid, and $E$ is the equivalent weight. To express the data in terms of carbon, $E=6$; to express it as $\mathrm{CO}_{2}, E=22$. The daily emission of carbon dioxide was expressed as $\mathrm{mg} \mathrm{CO}_{2}$ day $^{-1} \mathrm{~kg}^{-1}$ soil, while the cumulative carbon dioxide as $\mathrm{mg} \mathrm{CO} 2100 \mathrm{~g}^{-1}$ soil. 
Analysis of Residual Carbon, Carbon Balance, and Degradation Rate Constant ( $k$ Value)

At the end of 4 months, i.e., 120 days soil and residue samples were collected from the plastic pots for the analysis of residual OC. Carbon balance was calculated as given below:

Carbon balance $=$ input - output

where input is the inherent soil carbon + added carbon using residues and manure, and output is the carbon emission + residual carbon in soil.

Organic carbon degradation rate constant, $k$ was calculated using the following first-order simple kinetic model [21].

$\operatorname{Ln}\left(C / C_{0}\right)=-k t$

where $C$ and $C_{0}$ are the final and initial carbon contents, respectively; $t$ is the time, either day or year.

\section{Statistical Analysis}

SPSS version 12.0 statistical software [15] was used to analyze the data. ANOVA and univariate analysis were performed.

\section{Results and Discussion}

From the trend of $\mathrm{CO}_{2}$ emission, it was observed that in all types of residues and manures, emission drastically reduced after 1-3 weeks of incubation. The emission of $\mathrm{CO}_{2}$ varied among the treatments corresponding with each date of sampling. The maximum emission was recorded in the first week of incubation (Fig. 1a-c). After 3 weeks of incubation, $\mathrm{CO}_{2}$ emission came down sharply and finally approached almost zero to $5 \mathrm{mg} \mathrm{CO}$ day $^{-1} \mathrm{~kg}^{-1}$ soil in all types of residues and manures irrespective of water management options. The lowest amount of $\mathrm{CO}_{2}$ emission was recorded in the control pots (Fig. 1a) where only soil was used, while the highest amount found from poultry manure (Fig. 1c). At the first 4 days of incubation under continuously moist condition, carbon dioxide emission was about $4.5 \mathrm{mg}$ $\mathrm{CO}_{2}$ day $^{-1} \mathrm{~kg}^{-1}$ soil in the control treatment (Fig. 1a), $26 \mathrm{mg} \mathrm{CO}_{2}$ day $^{-1} \mathrm{~kg}^{-1}$ when poultry manure added to soil (Fig. 1b), while it was about $34 \mathrm{mg} \mathrm{CO}_{2}$ day $^{-1} \mathrm{~kg}^{-1}$ soil in the sole poultry manure applied pots (Fig. 1c). Rice straw mixed with soil released $11 \mathrm{mg} \mathrm{CO}_{2}$ day ${ }^{-1} \mathrm{~kg}^{-1}$ under alternate wetting and drying condition and $9 \mathrm{mg} \mathrm{CO}_{2}$ day $^{-1} \mathrm{~kg}^{-1}$ under continuously moist condition at the first 4 days of incubation (Fig. 1a), while these values were 6 and $9 \mathrm{mg} \mathrm{CO}_{2}$ day $^{-1} \mathrm{~kg}^{-1}$, respectively when cowdung was applied (Fig. 1b). Poultry manure released high amount of $\mathrm{CO}_{2}$ because it contains high amount of total nitrogen $(2.09 \%)$, and $\mathrm{C}: \mathrm{N}$ ratio is low compared with other materials (Table 1), which favors rapid microbial decomposition. Manure with higher contents of nitrogen and moisture tremendously increased $\mathrm{CO}_{2}$ emission [13]. Moreover, poultry manure contains high amount of soluble or labile carbon. It was reported that if organic matter added to soil containing high amount of labile carbon potentially enhances $\mathrm{CO}_{2}$ emission and thus restricts carbon accumulation in soil [23]. The trend of $\mathrm{CO}_{2}$ emission from different organic materials where emission dropped down after 3 weeks of incubation forced us to rethink the direct use of these materials in agriculture. Anaerobic digestion and composting could be the alternative environment-friendly practice, which reduces greenhouse gases to the atmosphere and also provides biogas to replace fossil fuel and nutrient-enriched compost to be used as fertilizer. Anaerobic digestion has recently drawn attention of the scientists and policymakers to address climate change mitigation.

In general, after incorporation of residues to soils, it takes time for starting microbial activities. The study was conducted in the laboratory condition; therefore, data might not correlate with the field condition because of environmental diversity and heterogeneity. Organic matter in soil is broken down through microbial degradation, root

Table 2 Cumulative $\mathrm{CO}_{2}$ emission and carbon degradation rate constant under different residues and alternate wetting and drying and moist conditions

\begin{tabular}{|c|c|c|}
\hline Treatment factors & $\begin{array}{l}\text { Cumulative } \mathrm{CO}_{2} \text { emission } \\
\left(\mathrm{mg} \mathrm{CO}_{2} 100 \mathrm{~g}^{-1} \text { at }\right. \\
118 \text { days })\end{array}$ & $\begin{array}{l}\text { Carbon degradation } \\
\text { rate constant, } \\
k\left(\text { day }^{-1}\right)\end{array}$ \\
\hline \multicolumn{3}{|l|}{ Residues or C source } \\
\hline Soil & $158.40 \mathrm{f}$ & $0.002090 \mathrm{~d}$ \\
\hline Soil + RS & $312.84 d$ & $0.002834 \mathrm{c}$ \\
\hline Soil + RR & $365.80 \mathrm{c}$ & $0.002393 \mathrm{c}$ \\
\hline Soil + CD & $283.10 \mathrm{e}$ & $0.002077 \mathrm{~d}$ \\
\hline Soil + PM & $576.18 \mathrm{a}$ & $0.004185 b$ \\
\hline RS & $441.04 b$ & $0.005104 \mathrm{a}$ \\
\hline $\mathrm{RR}$ & $472.23 b$ & $0.001573 d$ \\
\hline $\mathrm{CD}$ & $386.10 \mathrm{c}$ & $0.000429 \mathrm{e}$ \\
\hline PM & $580.64 a$ & $0.003160 \mathrm{c}$ \\
\hline S.E. & 30.04 & 0.001 \\
\hline \multicolumn{3}{|l|}{ Water management } \\
\hline $\begin{array}{l}\text { Alternate wetting } \\
\text { and drying }\end{array}$ & 408.76 & $0.003059 a$ \\
\hline $\begin{array}{l}\text { Continuously } \\
\text { moist }\end{array}$ & 386.00 & $0.002311 b$ \\
\hline S.E. & 25.08 & 0.000 \\
\hline $\begin{array}{l}\text { Residues } \times \text { water } \\
\text { management }\end{array}$ & NS & NS \\
\hline
\end{tabular}

$C D$ cowdung, $P M$ poultry manure, $R S$ rice straw, $R R$ rice root 
Fig. 2 Cumulative carbon dioxide emission from different organic residues under alternate wetting and drying and moist condition throughout 118 days of incubation, a soil, soil plus rice straw and soil plus rice roots, $\mathbf{b}$ soil plus cowdung and soil plus poultry manure, $\mathbf{c}$ rice straw, rice roots, cowdung and poultry manure $A W D$ alternate wetting and drying, $C M$ continuously moist, $C D$ cowdung, $P M$ poultry manure, $R S$ rice straw, $R R$ rice root
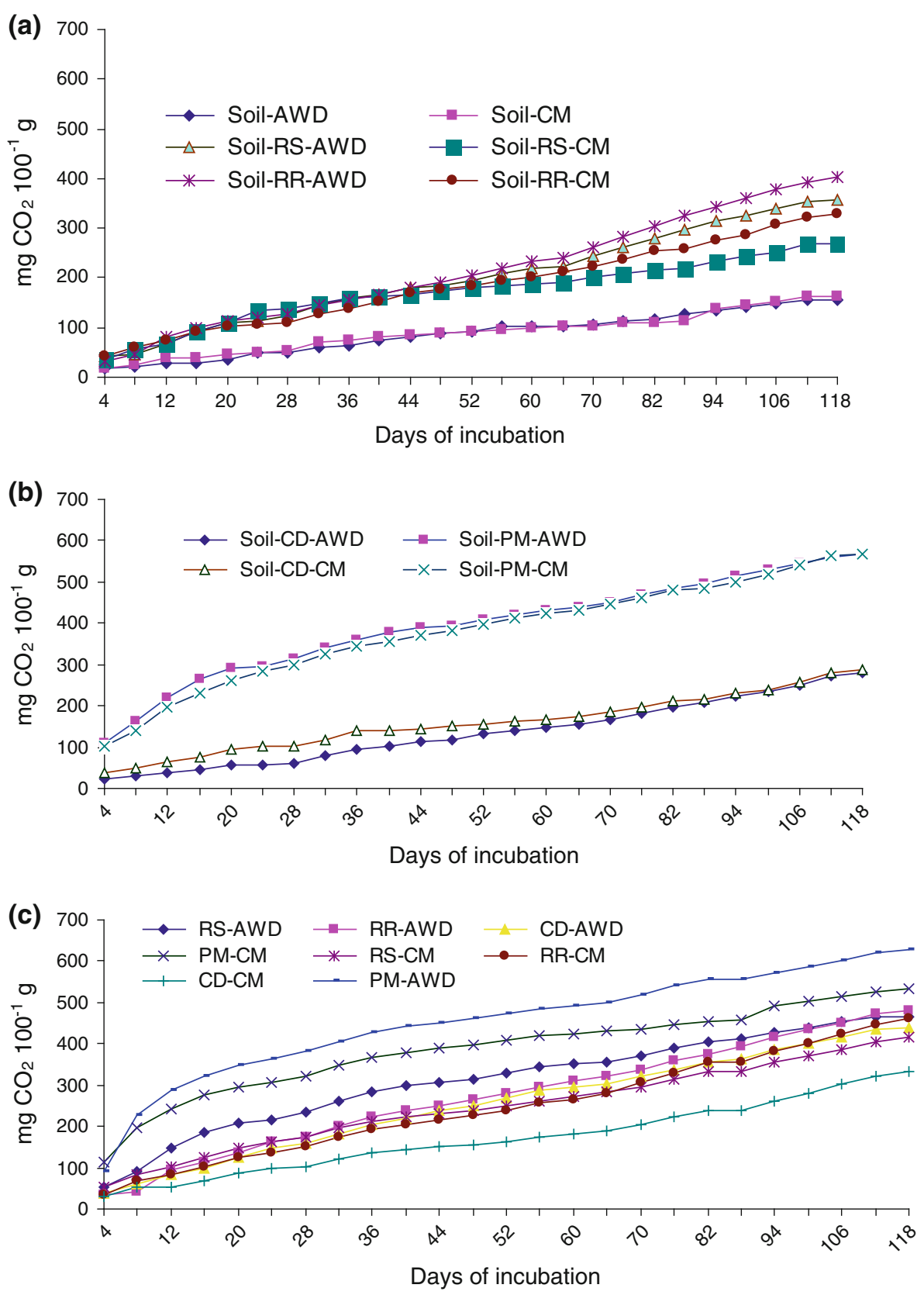

and faunal respiration, and released $\mathrm{CO}_{2}$, which is influenced by many factors like soil and temperature, alternate wetting and drying, and composition of organic residues. Soil microflora contributes $99 \%$ of the $\mathrm{CO}_{2}$ arising as a result of decomposition of organic matter [16]. Composition of organic residues affects their microbial degradation. The presence of higher percentage of cellulose, hemicellulose, and lignin in rice straw and roots slows down its microbial decomposition and thereby limits $\mathrm{CO}_{2}$ emission [24].

The effect of carbon source on cumulative emission of $\mathrm{CO}_{2}$ at the end of 118 days of incubation was found to be significant, while the effect of water management and the interaction of residues and water management were found to be insignificant (Table 2). The lowest cumulative emission of $\mathrm{CO}_{2}\left(158 \mathrm{mg} \mathrm{CO}_{2} 100 \mathrm{~g}^{-1}\right)$ was in the control treatment, i.e., where no residues were added, while the highest was recorded either from the only poultry manure (580 mg CO $100 \mathrm{~g}^{-1}$ ) or poultry manure plus soil (576 mg CO $100 \mathrm{~g}^{-1}$ ). The cumulative emissions from rice straw and cowdung mixed soils were 313 and $283 \mathrm{mg}$ $\mathrm{CO}_{2} 100 \mathrm{~g}^{-1}$, respectively, which were significantly lower than all other treatments except the control. The trends of cumulative emission of $\mathrm{CO}_{2}$ of the treatments corresponding with each date of sampling during the incubation periods were shown in the Fig. 2a-c. 
Table 3 Carbon balance under different residues and alternate wetting and drying and continuously moist conditions

\begin{tabular}{|c|c|c|c|c|c|c|c|}
\hline \multirow[t]{2}{*}{ Treatment factors } & \multicolumn{3}{|c|}{$\mathrm{C}$ input $(\mathrm{g})$} & \multicolumn{3}{|l|}{ C output (g) } & \multirow[t]{2}{*}{ C balance $(\mathrm{g})$} \\
\hline & Soil C & Residues C & Total & Emission $\mathrm{C}$ & Residual C & Total & \\
\hline \multicolumn{8}{|l|}{ Residues } \\
\hline Soil & 0.34 & 0 & 0.34 & $0.043 \mathrm{e}$ & $0.26 \mathrm{c}$ & 0.30 & $0.040 \mathrm{e}$ \\
\hline Soil + RS & 0.34 & 0.25 & 0.59 & $0.085 \mathrm{~d}$ & $0.42 \mathrm{a}$ & 0.51 & $0.080 \mathrm{a}$ \\
\hline Soil + RR & 0.34 & 0.25 & 0.59 & $0.100 \mathrm{c}$ & $0.43 \mathrm{a}$ & 0.53 & $0.060 \mathrm{c}$ \\
\hline Soil + CD & 0.34 & 0.25 & 0.59 & $0.077 \mathrm{~d}$ & $0.46 a$ & 0.54 & $0.050 \mathrm{~d}$ \\
\hline Soil + PM & 0.34 & 0.25 & 0.59 & $0.157 \mathrm{a}$ & $0.36 \mathrm{~b}$ & 0.52 & $0.070 \mathrm{~b}$ \\
\hline RS & 0 & 0.25 & 0.25 & $0.120 \mathrm{~b}$ & $0.14 \mathrm{e}$ & 0.26 & $-0.010 \mathrm{e}$ \\
\hline $\mathrm{RR}$ & 0 & 0.25 & 0.25 & $0.130 \mathrm{~b}$ & $0.21 \mathrm{~cd}$ & 0.34 & $-0.090 \mathrm{~g}$ \\
\hline $\mathrm{CD}$ & 0 & 0.25 & 0.25 & $0.105 \mathrm{c}$ & $0.24 \mathrm{c}$ & 0.35 & $-0.100 \mathrm{~g}$ \\
\hline PM & 0 & 0.25 & 0.25 & $0.158 \mathrm{a}$ & $0.17 \mathrm{de}$ & 0.33 & $-0.080 \mathrm{f}$ \\
\hline S.E. & - & - & - & 0.007 & 0.014 & - & 0.013 \\
\hline \multicolumn{8}{|l|}{ Water management } \\
\hline Alternate wetting and drying & 0.19 & 0.22 & 0.41 & $0.112 \mathrm{a}\left(411 \mathrm{mg} \mathrm{CO} \mathrm{CO}_{2}\right)$ & $0.29 b$ & 0.40 & 0.010 \\
\hline Continuously moist & 0.19 & 0.22 & 0.41 & $0.104 \mathrm{~b}(381 \mathrm{mg} \mathrm{CO} 2)$ & $0.31 \mathrm{a}$ & 0.41 & 0.000 \\
\hline S.E. & - & - & - & 0.003 & 0.007 & - & 0.006 \\
\hline Residues $\times$ water management & & & & NS & NS & & NS \\
\hline
\end{tabular}

$C D$ cowdung, $P M$ poultry manure, $R S$ rice straw, $R R$ rice root

The rates of carbon degradation were significantly affected by carbon source and water management $(p<0.05)$, while the interaction effect of carbon source and water management was found to be insignificant $(p>0.05)$. Carbon degradation rate constants $(k)$ in the present study varied from 0.000429 to 0.005104 day $^{-1}$ (Table 2). Jorgensen [8] found a $k$ value of 0.00001-0.0008 for mineral soil. The lowest $k$ value was found in the cowdung-applied pots, while the highest was under the rice straw-used pots. The carbon content was high in rice straw. The emission of carbon dioxide from rice straw was low, while the $k$ value was found to be high. This could be explained in this way that the $\mathrm{C}: \mathrm{N}$ ratio of rice straw is generally high, which needs several cycles of microorganism and obviously extra time to decompose it. During breakdown process, microbes use substrate carbon as a source of energy and build up their body. The biomass of bacteria, fungi, and actinomycetes are composed of $50 \%$ carbon [2]. Therefore, large amounts of carbon will be synthesized in microbial body and therefore, less amount of carbon will be released in soil.

The emission of $\mathrm{CO}_{2}$ as $\mathrm{C}$ and residual $\mathrm{C}$ in soils was significantly influenced by sources of carbon and water management options (Table 3). However, the interaction effect of carbon source and water management on carbon dioxide emission was found to be insignificant $(p>0.05)$. Though the carbon contents in the rich straw and even in the roots were high, the emission of carbon dioxide, however, was higher in the poultry manure-mixed pots. During 118 days of incubation, the total amount of carbon dioxide released from only poultry manure-containing pot was $0.156 \mathrm{~g}$, which was insignificantly different when poultry manure was mixed with soil. The total emission of $\mathrm{CO}_{2}$ as $\mathrm{C}$ over the 118 days of incubation under the control treatment, i.e., in the pot where only $100 \mathrm{~g}$ soil used was only $0.043 \mathrm{~g}$. Alternate wetting and drying condition was found to be more efficient to release carbon dioxide from soil over moist condition. From the carbon balance study total emission of carbon dioxide as $\mathrm{C}$ under alternate wetting and drying condition was recorded as $0.112 \mathrm{~g}$ (411 $\mathrm{mg} \mathrm{CO}$ ), while it was $0.104 \mathrm{~g}(381 \mathrm{mg} \mathrm{CO}$ ) in case of moist condition (Table 3 ), which strongly correlated with cumulative emission of $\mathrm{CO}_{2}$ as given in the Table 2. Data on residual $\mathrm{C}$ indicated that rice straw and cowdung were found to be more efficient to increase $\mathrm{C}$ contents in soils. On the other hand, continuously moist condition was observed to significantly increase $\mathrm{C}$ contents in soils relative to the alternate wetting and drying condition. Oxygen is only sparingly soluble in water and diffuses slowly [20]. Little amount of oxygen is present in saturated soils in the form of dissolved $\mathrm{O}_{2}$, which is quickly consumed through metabolic processes. Oxygen is used as terminal electron acceptor via respiration by roots, soil microbes, and soil organisms $[18,22]$, and is lost from the soil system in the form of carbon dioxide. Heterotrophic respiration may completely deplete oxygen in submerged soils, which may be observed within only a few millimeters of the soil surface [20]. Owing to the deficiency of oxygen in flooded soils, aerobic bacteria die or remain dormant, which limits microbial transformations of organic materials and thereby 
reduces $\mathrm{CO}_{2}$ emission under continuously moist condition; moreover, available carbon dioxide reduced to methane [14]. This finding is also cross checked and confirmed from organic matter degradation rate constant, $k$ (Table 2). The $k$ value was higher under alternate wetting and drying condition than that under moist condition (Table 2). Anaerobic recycling of wastes during the long-term incubation results in a lower net residue-C mineralization in flooded systems compared with nonflooded conditions [14]. Therefore, carbon content in soil was found to be higher under continuously moist condition, and conversely $\mathrm{CO}_{2}$ emission was lower compared with alternate wetting and drying condition.

Source of carbon, i.e., the residues significantly affected carbon balance, while, water management and interaction of residue and water management was found insignificant (Table 3). The negative sign of carbon balance revealed that carbon content in soil increased, where carbon output was found to be higher than carbon input. This might be interesting for discussion. Soil is a complex and heterogeneous body where carbon cycling and its transformations are regulated by different physical, chemical, and biological activities. When plant residues and manures are applied to the soil, various organic compounds undergo decomposition. Decomposition is a biological process that includes the physical breakdown and biochemical transformation of complex organic molecules of dead material into simpler organic and inorganic molecules. The addition of residues and manures to the soil surface contributes to the biological activity and the carbon cycling process in the soil. Several generations of different microbes in this process die and add carbon in soils. Carbon cycling is the continuous transformation of organic and inorganic carbon compounds by plants and micro and macroorganisms among the soil, plants and the atmosphere. In cultivated organic soils, about $450-4,500 \mathrm{~kg}$ of bacteria is present in per hectare-furrow slice, while fungi are present at $1,120-11,200 \mathrm{~kg}$ and actinomycetes are present at $450-4,500 \mathrm{~kg}$ [3]. Bacteria, fungi, and actinomycetes contain $50 \%$ carbon [2]. Therefore, a significant amount of carbon will be added to soils.

\section{Conclusions}

The peak of $\mathrm{CO}_{2}$ emission was recorded during the first week of incubation and after 3 weeks, it came down sharply and finally approached almost zero to $5 \mathrm{mg} \mathrm{CO}$ day ${ }^{-1} \mathrm{~kg}^{-1}$ irrespective of organic materials and water management. At the first 4 days of incubation the emission in the control treatment was about $4.5 \mathrm{mg} \mathrm{CO}_{2}$ day $^{-1} \mathrm{~kg}^{-1}$ soil, while it was about $34 \mathrm{mg} \mathrm{CO}$ day $^{-1} \mathrm{~kg}^{-1}$ from the sole poultry manure and $26 \mathrm{mg} \mathrm{CO} \mathrm{CO}_{2} \mathrm{day}^{-1} \mathrm{~kg}^{-1}$ from poultry manure plus soil. The carbon contents in the rich straw and roots were high; however, the emission of $\mathrm{CO}_{2}$ was higher in the poultry manure. Among the organic residues and manures, cowdung released less $\mathrm{CO}_{2}$, which was almost half of the amount released by poultry manure. Moreover, addition of cowdung increased $28 \%$ soil carbon over poultry manure. During 118 days of incubation cumulative emission were $158,313,366,283$, and $576 \mathrm{mg}$ $\mathrm{CO}_{2} 100 \mathrm{~g}^{-1}$ from only soil, soil plus rice straw, soil plus rice roots, soil plus cowdung, and soil plus poultry manure, respectively. The potential of $\mathrm{CO}_{2}$ emissions of different treatments were in the order of poultry manure $>$ soil plus poultry manure $>$ rice root $>$ rice straw $>$ cowdung $>$ soil plus rice root $>$ soil plus rice straw $>$ soil plus cowdung $>$ soil. Under alternate wetting and drying condition more $\mathrm{CO}_{2}$ was released than that under continuously moist condition. Data revealed that application of cowdung in agriculture can restrict $\mathrm{CO}_{2}$ emission compared with other organic materials. From the findings, it could be apprehended that before application to soil, composting of organic materials through anaerobic digestion could be the alternative environment-friendly practice, which reduces greenhouse gases to the atmosphere and also provides biogas to replace fossil fuel and nutrient-enriched compost to be used as fertilizer. Anaerobic digestion of organic materials has recently drawn attention of the scientists and policymakers to address climate change mitigation.

\section{References}

1. Agehara S, Warncke DD (2005) Soil alternate wetting and drying pure and temperature effects on nitrogen release from organic nitrogen sources. Soil Sci Soc Am J 69:1844-1855

2. Boyd CE (1995) Bottom soils, sediment and pond aquaculture. Chapman \& Hall, New York

3. Brady NC (2001) The nature and properties of soils. PrenticeHall of India Private Ltd, New Delhi

4. Franzluebbers AJ, Doraiswamy PC (2007) Carbon sequestration, and land degradation. In: Climate and land degradation, chapter 18. Springer, Berlin, pp 343-358

5. Gnanavelrajah N, Shrestha RP, Schmidtvogt D, Samarakoon L (2008) Carbon stock assessment and Soil carbon management in agricultural land-uses in Thailand. Land Degrad Dev 19:242-256

6. IPCC (1996) Climate change 1995. Impacts, adaptations and mitigation of climate change: scientific, technical analysis. Working group II, Cambridge University Press Cambridge

7. Jain MC, Pathak H, Bhatia A (2003) Measurement of greenhouse emission from soil and developing emission inventories. In: Pathak H, Kumer S (eds) Soil and greenhouse effect monitoring and evaluation. CBS Publishers and Distributors, New Delhi, pp 6578

8. Jorgensen SE (1979) Handbook of environmental data and ecological parameters. Pergamon Press, Oxford

9. Kundu S, Bhattacharyya RPV, Ghosh BN, Gupta HS (2006) Carbon sequestration and relationship between carbon addition 
and storage under rain fed soybean-wheat rotation in a sandy loam soil of the Indian Himalayas. Soil Till Res 92:87-95

10. Lal R (2001) Soil carbon sequestration and climate change. Senate Hearing, Science and Technical Sub-Committee, 24 May, Washington, DC

11. Lal R (2006) Enhancing crop yields in the developing countries through restoration of the soil organic carbon pool in agricultural lands. Land Degrad Dev 17:197-209

12. Lee J, Six J, King AP, van Kessel C, Rolston D (2006) Tillage and field scale controls on greenhouse gas emission. J Environ Qual 35:714-725

13. Ni JQ, Heber AJ, Hanni SM, Lim TT, Diehl CA (2010) Characteristics of ammonia and carbon dioxide releases from layer hen manure. Br Poult Sci 51(3):326-334

14. Oliver CD, Horwath WR (2000) Decomposition of rice straw and microbial carbon use efficiency under different soil temperatures and alternate wetting and drying. Soil Biol Biochem 32:17731785

15. Pallant P (2010) SPSS survival manual: a step by step data analysis using SPSS. McGraw Hill, New York

16. Rahman MM (2010) Carbon sequestration options in soils under different crops and their management practices. Agriculturists 8(1):90-101
17. Rastogi M, Singh S, Pathak H (2002) Emission of carbon dioxide from soil. Curr Sci 82:510-517

18. Reichle DE, McBrayer JF, Ausmus BS (1975) Progress in soil zoology. Academic Publishing, Czechoslovakia, pp 283-292

19. Russell AE, Larid DA, Parkin TB, Mallarino AP (2005) Impact of nitrogen fertilization and cropping system on carbon sequestration in Midwestern Mollisols. Soil Sci Soc Am J 69:413-422

20. Schlesinger WH (1997) Biogeochemistry: an analysis of global change, 2nd edn. Elsevier Academic Press, Amsterdam

21. Stanford G, Smith SJ (1972) Nitrogen mineralization potentials of soils. Soil Sci Soc Am Proc 36:465-472

22. Sylvia DM, Fuhrmann JJ, Hartel PG, Zuberer DA (2005) Principles and applications of soil microbiology, 2nd edn. Pearson Prentice Hall, New Jersey

23. Tanvea L, Gozalez-Meler MA (2008) Decomposition kinetics of soil carbon of different age from a forest exposed to 8 years of elevated atmospheric $\mathrm{CO}_{2}$ concentration. Soil Biol Biochem 40:2670-2677

24. Walli TK, Orskov ER, Bhargava PK (1988) Rumen degradation of straw. 3. Botanical fractions of two rice straw varieties and effects of ammonia treatment. Anim Prod 46:347-352

25. WMO (2012) World Meteorological Organization. Greenhouse gas bulletin, No. 8. http://www.wmo.int/pages/prog/arep/gaw/ ghg/documents/GHG_Bulletin_No.8_en.pdf 